\title{
KARAKTERISTISASI DAN UJI HOMOGENITAS KANDIDAT BAHAN ACUAN BUFER FTALAT DAN BUFER FOSFAT UNTUK PENGUKURAN DERAJAT KEASAMAN
}

\section{CHARACTERIZE AND HOMOGENEITY TEST OF PHTHALATE AND PHOSPHATE BUFFER AS REFERENCE MATERIALS CANDIDATE FOR DETERMINATION OF ACIDIC VALUE}

\author{
Sujarwo dan Nuryatini \\ Pusat Penelitian Kimia - Lembaga Ilmu Pengetahuan Indonesia \\ Kawasan PUSPIPTEK Serpong, Tangerang Selatan, Banten 15314 \\ Email: sujarwo86@gmail.com
}

Diterima : 2 Desember 2012, Direvisi : 9 Januari 2013, Disetujui : 17 Januari 2013

\begin{abstract}
ABSTRAK
Pengukuran $\mathrm{pH}$ sangat erat kaitannya dengan kehidupan sehari-hari seperti bidang lingkungan, makanan dan minuman, obat-obatan, bahkan proses metabolisme yang berlangsung dalam tubuh manusia. Untuk memperoleh nilai $\mathrm{pH}$ yang akurat, $\mathrm{pH}$ meter yang digunakan harus dikalibrasi secara rutin dan dicek performanya setiap kali akan digunakan. Kalibrasi dan pengecekan tersebut memerlukan standar yang tertelusur nilainya. Standar tersebut harus mengacu kebahan acuan atau CRM (Certified Reference Materials). Pusat Penelitian Kimia - LIPI sebagai laboratorium pelaksana teknis metrology kimia di Indonesia melakukan kegiatan penelitian pembuatan bahan acuan pengukuran $\mathrm{pH}$. Bahan acuan yang dibuat tersebut berupa buferft alat dan buffer fosfat dengan nilai $\mathrm{pH}$ pada $25^{\circ} \mathrm{C}$ berturut-turut yaitu 4,00 $\pm 0,01$ dan $6,86 \pm 0,01$ pada tingkat kepercayaan 95\% (k=2). Uji homogenitas dievaluasi menggunakan uji $\mathrm{F}$ dan hasilnya menunjukkan bahwa kedua kandidat bahan acuan yang dibuat tersebut adalah homogeny.
\end{abstract}

Kata kunci : Bahan acuan, CRM, bufer Ftalat, bufer fosfat, ketidakpastian, homogenitas

\section{ABSTRACT}

Measurement of $\mathrm{pH}$ is closely related to everyday life, such as in the area of environment, food and beverage, pharmaceuticals, and even metabolism process in human body. To ensure the quality of $\mathrm{pH}$ measurement, $\mathrm{pH}$ meter should be calibrated regularly and checked each time before used. Calibration and performance checking of $\mathrm{pH}$ meter requires traceable standard. The standard should be linked to CRM (Certified Reference Materials). Research Center for Chemistry - Indonesian Institute of Sciencesas the technical laboratory in Indonesia for metrology in chemistry is conducting research in developing reference materials for $\mathrm{pH}$ measurement. The reference materials are phthalate and phosphate buffer withthe value of $\mathrm{pH}$ were $4.00 \pm 0.01$ and
$6.86 \pm 0.01$, respectively at $95 \%$ confidence level $(k=2)$. Homogenity study was evaluated based on F-test and the results indicated that both reference materials candidate were homogeneous.

Keywords: Reference materials, CRM, phthalate buffer, phosphate buffer, uncertainty, homogeneity.

\section{PENDAHULUAN}

Salah satu parameter kimia yang paling sering diukur di laboratorium pengujian adalah derajat keasaman (pH). Pengukuran $\mathrm{pH}$ sangat erat kaitannya dengan kehidupan sehari-hari terutama dalam bidang lingkungan, makanan dan minuman, obat-obatan, bahkan proses metebolisme yang berlangsung dalam tubuh manusia. Pada umumnya pengukuran $\mathrm{pH}$ di laboratorium dilakukan secara potensiometri menggunakan $\mathrm{pH}$ meter dengan elektroda gelas. Untuk menghasilkan nilai yang terpercaya, $\mathrm{pH}$ meter harus dikalibrasi secara rutin dengan menggunakan bahan acuan pengukuran $\mathrm{pH}$ yang tersertifikasi atau lebih dikenal sebagai bahan acuan/CRM (Certified Reference Material $)^{(1)}$. Selain itu, perlu dilakukan juga pengecekan unjuk kerja $\mathrm{pH}$ meter setiap kali akan digunakan untuk melakukan pengukuran $\mathrm{pH}$. Kalibrasi dan pengecekan tersebut menggunakan bahan acuan/CRM baik pada level primer, sekunder maupun standar kerja.

Selama ini laboratorium-laboratorium tersebut memperoleh bahan acuan/CRM untuk pengukuran $\mathrm{pH}$ dari perusahaan produsen CRM asal negara-negara maju seperti Jerman, Jepang, USA, dan lain-lain. Oleh 
karena impor, harga bahan acuan pengukuran $\mathrm{pH}$ tersebut relatif mahal. Padahal ketahanan (self life) dari bahan acuan tersebut pada umumnya hanya dua tahun jika masih dalam keadaan tertutup atau enam bulan jika sudah dibuka. Sehingga laboratorium harus membeli standar pengukuran $\mathrm{pH}$ secara rutin untuk menjamin keakuratan pengukuran $\mathrm{pH}$ di laboratorium masingmasing.

Pusat Penelitian Kimia - LIPI yang merupakan laboratorium rujukan pelaksana teknis metrologi kimia, dimana salah satu tupoksinya yaitu mendiseminasikan ketertelusuran pengujian kimia dari SI kepada laboratorium-laboratorium di Indonesia saat ini melalui kegiatan DIPA sedang melakukan penelitian dan pengembangan pembuatan bahan acuan untuk pengukuran $\mathrm{pH}$. Pembuatan bahan acuan tersebut difokuskan pada bufer ftalat ( $\mathrm{pH}$ asam) dan bufer fosfat ( $\mathrm{pH}$ netral). Kedua larutan tersebut merupakan bahan acuan yang paling sering digunakan untuk mengkalibrasi dan melakukan pengecekan performa $\mathrm{pH}$ meter.

Untuk membuat bahan acuan, sesuai ISO Guide 34 dan 35 diperlukan studi yang komperhensif mulai dalam tahap pemrosesan, pengujian, evaluasi, dan aspek majamennya. Tahapan-tahapan tersebut mencakup pemilihan bahan baku, studi kelayakan untuk pemrosesan dan karakterisasi material, preparasi kandidat bahan acuan, penentuan nilai sertifikasi dan ketidakpastiannya, studi homogenitas, studi stabilitas jangka pendek dan jangka panjang, penyusunan sertifikat dan pelaporan sertifikat, peninjauan hasil proyek, serta penerimaan dokumen sertifikasi ${ }^{(2)}$. Selain itu, untuk memperoleh hasil yang valid, instrumen yang digunakan yaitu $\mathrm{pH}$ meter untuk menentukan nilai bahan acuan $\mathrm{pH}$ juga perlu dikalibrasi dan divalidasi menggunakan CRM. Begitu juga dengan peralatan lain seperti neraca dan alat-alat gelas juga harus dikalibrasi. $\mathrm{Hal}$ ini bertujuan untuk memperoleh hasil yang akurat dengan ketidakpastian pengukuran yang kecil. Tahapan yang dilakukan untuk mengkalibrasi $\mathrm{pH}$ meter adalah sebagai berikut:

1. Mengkalibrasi pH meter sebagai potensiometer

2. Mengkalibrasi pengukur temperatur di dalam $\mathrm{pH}$ meter

3. Mengkalibrasi elektroda gelas menggunakan bahan acuan/CRM

Untuk mengkalibrasi $\mathrm{pH}$ meter sebagai potensiometer digunakan sumber arus DC yang diketahui nilainya secara tepat dan tertelusur ke standar nasional potensial listrik (voltase) pada rentang potensial $-2000 \mathrm{mV}$ sampai dengan $+2000 \mathrm{mV}$. Kalibrasi pengukuran temperatur dilakukan dengan membandingkan nilai pembacaan temperatur pada $\mathrm{pH}$ meter dengan pembacaan temperatur menggunakan termometer yang tertelusur ke standar nasional ${ }^{(3)}$. Adapun untuk mengkalibrasi elektroda gelas dilakukan dengan menggunakan bahan acuan/CRM pada berbagai variasi $\mathrm{pH}$ (two-point calibration atau multi-point calibration).

Uji homogenitas sangat penting dilakukan dalam pembuatan bahan acuan. Untuk menentukan homogenitas sampel sesuai panduan KAN dapat ditetapkan dengan dua kriteria sebagai berikut ${ }^{(4)}$ :

1. Kriteria I berdasarkan uji $\mathrm{F}$ ( $F$-test)

$$
\begin{gathered}
\mathrm{F}=\frac{\mathrm{MSB}}{\mathrm{MSW}} \\
\operatorname{MSB}(\text { mean square between })=\frac{\sum\left[\left(\mathrm{a}_{\mathrm{i}}+\mathrm{b}_{\mathrm{i}}\right)-\overline{\mathrm{X}}_{\left(\mathrm{a}_{\mathrm{i}}+\mathrm{b}_{\mathrm{i}}\right)}\right]^{2}}{2(\mathrm{n}-1)}
\end{gathered}
$$

$\operatorname{MSW}($ mean square within $)=\frac{\sum\left[\left(\mathrm{a}_{\mathrm{i}}+\mathrm{b}_{\mathrm{i}}\right)-\overline{\mathrm{X}}_{\left(\mathrm{a}_{\mathrm{i}}+\mathrm{b}_{\mathrm{i}}\right)}\right]^{2}}{2 \mathrm{n}}$

$\mathrm{a}_{\mathrm{i}}=$ nilai pengukuran ke-1 dari sampel $\mathrm{i}$

$b_{i}=$ nilai pengukuran ke-2 (duplo) dari sampel $\mathrm{i}$

Sampel dinyatakan homogen jika $\mathrm{F}_{\text {hitung }}<\mathrm{F}_{\text {tabel }}$

Apabila $\mathrm{F}_{\text {hitung }}$ yang diperoleh lebih besar dari $\mathrm{F}_{\text {tabel, }}$,

maka homogenitas sampel dapat diuji dengan kriteria II.

2. Kriteria II berdasarkan 'perhitungan simpangan baku sampling' melalui persamaan:

$$
\begin{aligned}
& \mathrm{S}_{\mathrm{S}}=\sqrt{\frac{\mathrm{MSB}-\mathrm{MSW}}{2}} \\
& \mathrm{SD}_{\text {Horwitz }}=\frac{\mathrm{KV}_{\text {Horwitz }} \cdot \overline{\mathrm{X}}}{100} \\
& \mathrm{KV}_{\text {Horvitz }}=2^{(10,5 \log ) \mathrm{C}} \\
& \mathrm{C}=\frac{\mathrm{SD}_{\mathrm{a}}+\mathrm{SD}_{\mathrm{b}}}{2}
\end{aligned}
$$

Apabila $\mathrm{S}_{\mathrm{s}}<0,5 \mathrm{SD}_{\text {Horwitz }}$, maka sampel dinyatakan homogen.

\section{BAHAN DAN METODA}

\section{Bahan}

Bahan-bahan yang digunakan yaitu: Certipur secondary standard reference material $\mathrm{pH} 6,863 \pm 0,003$ $\left(25^{\circ} \mathrm{C}\right)$ dan $\mathrm{pH} 4,005 \pm 0,003\left(25^{\circ} \mathrm{C}\right)$ (Merck-Millipore) tertelusur ke NIST dan PTB; Kalium hidrogen ftalat 
$\left(\mathrm{KHC}_{8} \mathrm{H}_{4} \mathrm{O}_{4}\right)$ p.a (Merck-Millipore); Kalium hidrogen fosfat $\left(\mathrm{KH}_{2} \mathrm{PO}_{4}\right)$ p.a (Merck-Millipore); di-Natrium Hidrogen Fosfat $\left(\mathrm{Na}_{2} \mathrm{HPO}_{4}\right)$ p.a (Merck-Millipore); air demineral dengan konduktivitas elektrik $\leq 18,2 \mu \mathrm{S} / \mathrm{cm}$.

\section{Peralatan}

Peralatan yang digunakan dalam penelitian ini yaitu: $\mathrm{pH}$ meter Mettler Toledo MP230, USA dengan akurasi $0,001 \mathrm{pH} ; 0,1 \mathrm{mV}$; dan $0,2^{\circ} \mathrm{C}$; Magnetic stirrer IKA® RH-KTC, Malaysia; Neraca analitik Mettler Toledo AT 200, USA dengan akurasi 0,1 mg; Neraca analitik Mettler Toledo XP-1003S, USA dengan kapasitas maksimal $10 \mathrm{~kg}$ dan akurasi $1 \mathrm{mg}$; serta peralatan gelas standar yang biasa digunakan di laboratorium analitik.

\section{Metoda}

Untuk membuat kandidat bahan acuan bufer ftalat 0,05 molal $(\mathrm{mol} / \mathrm{kg})$, sebanyak $\pm 10,3 \mathrm{~g}$ kalium hidrogen ftalat $\left(\mathrm{KHC}_{8} \mathrm{H}_{4} \mathrm{O}_{4}\right)$ di dalam gelas kimia $1 \mathrm{~L}$, kemudian ditambahkan air demineral bebas $\mathrm{CO}_{2}$ sampai dengan diperoleh 97,887 kali massa penimbangan kalium hidrogen ftalat. Larutan tersebut dihomogenkan menggunakan magnetic stirrer selama \pm 10 menit. Pembuatan ini dilakukan sebanyak 10 kali pengulangan, lalu larutan yang dibuat tersebut dimasukkan ke dalam botol $20 \mathrm{~L}$ dan dihomogenkan. Dari sekitar 10 L larutan bufer yang diperoleh kemudian dikemas dalam botol plastik masing-masing volumenya $100 \mathrm{~mL}$ sehingga diperoleh 100 botol larutan bufer ftalat. Adapun pembuatan air demineral bebas $\mathrm{CO}_{2}$ yaitu dilakukan dengan mendidihkan air demineral kemudian didinginkan dalam keadaan tertutup. Air demineral yang telah dingin tersebut kemudian dihilangkan gasnya menggunakan vakum.

Pembuatan larutan bufer fosfat 0,025 molal (mol/kg) dilakukan dengan menimbang kalium hidrogen fosfat $\left(\mathrm{KH}_{2} \mathrm{PO}_{4}\right)$ sebanyak $\pm 3,6 \mathrm{~g}$ di dalam gelas kimia $1 \mathrm{~L}$. Kemudian dilarutkan dengan air demineral bebas $\mathrm{CO}_{2}$ sampai dengan diperoleh 293,730 kali massa penimbangan kalium hidrogen fosfat dan dihomogenkan menggunakan magnetic stirrer selama \pm 10 menit (larutan I). Sementara di dalam gelas kimia 1 $\mathrm{L}$ yang lain ditimbang sebanyak $\pm 3,6 \mathrm{~g}$ di-natrium hidrogen fosfat $\left(\mathrm{Na}_{2} \mathrm{HPO}_{4}\right)$, kemudian dilarutkan dengan larutan I sampai diperoleh 282,561 kali massa penimbangan di-natrium hidrogen fosfat dan dihomogenkan menggunakan magnetic stirrer selama \pm 10 menit. Pembuatan ini dilakukan sebanyak 10 kali pengulangan, lalu larutan tersebut dimasukkan ke dalam botol $20 \mathrm{~L}$ dan dihomogenkan. Dari sekitar $10 \mathrm{~L}$ larutan bufer yang diperoleh kemudian dikemas dalam botol plastik masing-masing volumenya $100 \mathrm{~mL}$ sehingga diperoleh 100 botol larutan bufer fosfat.

Larutan bufer ftalat dan bufer fosfat tersebut kemudian diukur potensialnya menggunakan $\mathrm{pH}$ meter yang telah dikalibrasi dan divalidasi pada suhu $25^{\circ} \mathrm{C}$

\section{HASIL DAN PEMBAHASAN}

Pada penelitian ini telah dilakukan kalibrasi $\mathrm{pH}$ meter menggunakan $\mathrm{pH}$ calibrator oleh perusahaan distributor $\mathrm{pH}$ meter. Pengukuran temperatur pada $\mathrm{pH}$ meter telah dicek menggunakan termometer terkalibrasi dan tertelusur ke standar nasional. Hasil menunjukkan bahwa nilai potensial listrik dan temperatur sesuai dengan kalibrator. Kemudian elektroda gelas dikalibrasi dan divalidasi menggunakan bahan acuan level sekunder $\mathrm{pH} 4,005 \pm 0,003$ dan $\mathrm{pH} 6,863 \pm 0,003$. Nilai slope yang diperoleh 98,9 - 99,1 \% dan potensial asimetrik pada $\mathrm{pH}$ netral $(7,00)$ adalah $\pm 0,2 \mathrm{mV}$. Hal ini menunjukkan bahwa $\mathrm{pH}$ meter mempunyai karakteristik yang sesuai untuk digunakan dalam pengukuran, dimana slope yang diperbolehkan yaitu antara $95 \%-102 \%$ dan potensial asimetrik pada $\mathrm{pH}$ netral maksimal $\pm 15 \mathrm{mV}^{(5)}$.

Nilai pengukuran potensial listrik dari bahan acuan sekunder ditunjukkan pada Tabel 1. Sedangkan nilai potensial listrik dari kandidat bahan acuan yang dibuat ditunjukkan pada Tabel 2.

Tabel 1. Pengukuran Potensial Listrik Bahan Acuan Sekunder

\begin{tabular}{lccccccccccc}
\hline $\begin{array}{l}\text { Kondisi } \\
\text { Pengukuran }\end{array}$ & $\mathrm{pH}$ & \multicolumn{10}{|c}{ Potensial (mV) } \\
\hline $\begin{array}{l}\text { Rentang } \\
\text { Waktu } \\
\text { Singkat }\end{array}$ & 4,005 & 166,5 & 166,6 & 166,7 & 166,6 & 166,7 & 166,7 & 166,8 & 166,8 & 166,8 & 166,8 \\
\hline $\begin{array}{l}\text { Rentang } \\
\text { Waktu }\end{array}$ & 4,005 & 166,2 & 16,9 & 1,0 & 1,0 & 1,0 & 1,0 & 1,0 & 1,1 & 1,0 & 1,1 \\
\cline { 2 - 15 } Panjang & 6,863 & 1,3 & 1,2 & 1,2 & 1,2 & 1,2 & 1,2 & 1,4 & 1,2 & 1,2 & 1,1 \\
\hline Paralel & 4,005 & 166,4 & 166,4 & 166,4 & 166,5 & 166,4 & 166,4 & 166,3 & 166,4 & 166,3 & 166,4 \\
\cline { 2 - 12 } & 6,863 & 0,9 & 0,8 & 0,7 & 0,7 & 0,6 & 0,6 & 0,9 & 0,7 & 0,6 & 0,7 \\
\hline
\end{tabular}

Tabel 2. Pengukuran Potensial Listrik Kandidat Bahan Acuan

\begin{tabular}{|c|c|c|c|c|c|c|c|c|c|c|c|}
\hline \multirow{3}{*}{$\begin{array}{l}\text { Pengukuran } \\
\text { Rentang } \\
\text { Waktu } \\
\text { Singkat }\end{array}$} & \multirow{2}{*}{$\begin{array}{c}\text { Sampel } \\
\text { Buffer } \\
\text { Ftalat }\end{array}$} & \multicolumn{10}{|c|}{ Potensial (mV) } \\
\hline & & 166,6 & 166,8 & 167,0 & 167,1 & 167,1 & 167,2 & 167,3 & 167,5 & 167,5 & 167,7 \\
\hline & $\begin{array}{c}\text { Buffer } \\
\text { Fosfat } \\
\end{array}$ & 0.9 & 1,0 & 1,0 & 1,1 & 1,1 & 1,1 & 1,1 & 1,1 & 1,0 & 1,1 \\
\hline \multirow{2}{*}{$\begin{array}{l}\text { Rentang } \\
\text { Waknu } \\
\text { Panjang } \\
\end{array}$} & $\begin{array}{l}\text { Buffer } \\
\text { Ftalat } \\
\end{array}$ & 166,1 & 166,2 & 166,1 & 166,2 & 166,1 & 166,3 & 166,1 & 166,2 & 166,1 & 166,2 \\
\hline & $\begin{array}{l}\text { Bufer } \\
\text { Fosfat }\end{array}$ & 0,5 & 0,6 & 0,7 & 0,7 & 0,6 & 0,6 & 0,5 & 0.5 & 0,6 & 0,7 \\
\hline \multirow{2}{*}{ Paralel } & $\begin{array}{l}\text { Buter } \\
\text { Ftalat }\end{array}$ & 166,7 & 166,8 & 166.5 & 166,6 & 166,5 & 166,6 & 166,6 & 166,8 & 166.5 & 166,6 \\
\hline & $\begin{array}{c}\text { Bufer } \\
\text { Fosfat }\end{array}$ & 0,8 & 0,8 & 0,8 & 0,8 & 0,8 & 0,7 & 0,6 & 0,6 & 0,7 & 0,7 \\
\hline
\end{tabular}

Perhitungan nilai $\mathrm{pH}$ pada $25^{\circ} \mathrm{C}$ menggunakan twopoint calibration (bracketing procedure) berdasarkan rumus berikut ${ }^{(\mathscr{)})}$ :

$$
\begin{aligned}
& \mathrm{pH}(\mathrm{X})=\mathrm{pH}\left(\mathrm{S}_{1}\right)-\frac{\left[\mathrm{E}_{\mathrm{v}}(\mathrm{X})-\mathrm{E}_{\mathrm{v}}\left(\mathrm{S}_{1}\right)\right]}{k^{\prime}} \\
& k^{\prime}=\frac{\left[\mathrm{E}_{\mathrm{v}}\left(\mathrm{S}_{1}\right)-\mathrm{E}_{\mathrm{V}}\left(\mathrm{S}_{2}\right)\right]}{\left[\mathrm{pH}\left(\mathrm{S}_{2}\right)-\mathrm{pH}\left(\mathrm{S}_{1}\right)\right]}
\end{aligned}
$$


$\mathrm{pH}(\mathrm{X})$ adalah nilai $\mathrm{pH}$ larutan bufer yang akan ditentukan; $\mathrm{pH}\left(\mathrm{S}_{1}\right)$ adalah nilai $\mathrm{pH}$ bahan acuan ke-1; $\mathrm{pH}\left(\mathrm{S}_{2}\right)$ adalah nilai $\mathrm{pH}$ bahan acuan ke-2; $\mathrm{E}_{\mathrm{v}}(\mathrm{X})$ adalah nilai potensial listrik larutan bufer yang akan ditentukan; $\mathrm{E}_{\mathrm{v}}\left(\mathrm{S}_{1}\right)$ adalah potensial listrik bahan acuan ke-1; dan $\mathrm{E}_{\mathrm{v}}\left(\mathrm{S}_{2}\right)$ adalah potensial listrik bahan acuan ke2. Berdasarkan perhitungan tersebut nilai $\mathrm{pH}$ kandidat bahan acuan bufer ftalat dan bufer fosfat berturut-turut adalah 4,00 dan 6,86 (hasil perhitungan pada Tabel 3).

Tabel 3. Perhitungan Nilai pH Kandidat Bahan Acuan

\begin{tabular}{|c|c|c|c|c|c|c|c|c|}
\hline \multirow{2}{*}{ No. } & \multicolumn{2}{|c|}{$\mathrm{pH}(\mathrm{S} 1)=4,005$} & \multicolumn{2}{|c|}{$\mathrm{pH}(\mathrm{S} 2)=6,863$} & \multicolumn{2}{|c|}{ Bufer Ftalat } & \multicolumn{2}{|c|}{ Bufer Fosfat } \\
\hline & $\begin{array}{l}\mathbf{E}_{\mathrm{v}}\left(\mathbf{S}_{1}\right) \\
(\mathrm{mV})\end{array}$ & $\begin{array}{c}\mathbf{E}_{\mathbf{v}}\left(\mathbf{S}_{1}\right) \\
(\mathrm{V})\end{array}$ & $\begin{array}{l}\mathbf{E}_{\mathbf{V}}\left(\mathbf{S}_{2}\right) \\
(\mathrm{mV})\end{array}$ & $\begin{array}{c}\mathbf{E}_{\mathbf{v}}\left(\mathbf{S}_{2}\right) \\
(\mathbf{V})\end{array}$ & $\begin{array}{l}\mathbf{E}_{\mathrm{v}}\left(\mathbf{X}_{\mathbf{l}}\right) \\
(\mathbf{m V})\end{array}$ & $\begin{array}{c}\mathbf{E}_{\mathbf{v}}\left(\mathbf{X}_{\mathbf{1}}\right) \\
(\mathbf{V})\end{array}$ & $\begin{array}{r}\mathbf{E}_{V}\left(\mathbf{X}_{2}\right. \\
(\mathrm{mV})\end{array}$ & $\begin{array}{c}\mathbf{E}_{\mathbf{v}}\left(\mathbf{X}_{2}\right) \\
(\mathbf{V})\end{array}$ \\
\hline 1. & 166,4 & 0,1664 & 0,9 & 0,0009 & 166,7 & 0,1667 & 0,8 & 0,0008 \\
\hline 2. & 166,4 & 0,1664 & 0,8 & 0,0008 & 166,8 & 0,1668 & 0,8 & 0,0008 \\
\hline 3. & 166,4 & 0,1664 & 0,7 & 0,0007 & 166,5 & 0,1665 & 0,8 & 0,0008 \\
\hline 4. & 166,5 & 0,1665 & 0,7 & 0,0007 & 166,6 & 0,1666 & 0,8 & 0,0008 \\
\hline 5. & 166,4 & 0,1664 & 0,6 & 0,0006 & 166,5 & 0,1665 & 0,8 & 0,0008 \\
\hline 6. & 166,4 & 0,1664 & 0,6 & 0,0006 & 166,6 & 0,1666 & 0,7 & 0,0007 \\
\hline 7. & 166,3 & 0,1663 & 0,9 & 0,0009 & 166,6 & 0,1666 & 0,6 & 0,0006 \\
\hline 8. & 166,4 & 0,1664 & 0,7 & 0,0007 & 166,8 & 0,1668 & 0,6 & 0,0006 \\
\hline 9. & 166,3 & 0,1663 & 0,6 & 0,0006 & 166,5 & 0,1665 & 0,7 & 0,0007 \\
\hline 10. & 166,4 & 0,1664 & 0,7 & 0,0007 & 166,6 & 0,1666 & 0,7 & 0,0007 \\
\hline & ta (V) & 0,16639 & & 0,00072 & & 0,16662 & & 0,00073 \\
\hline
\end{tabular}

1. Perhitungan Nilai pH Kandidat Bahan Acuan Bufer Ftalat

$$
\begin{aligned}
& k^{\prime}=\frac{\left[\mathrm{E}_{\mathrm{V}}\left(\mathrm{S}_{1}\right)-\mathrm{E}_{\mathrm{V}}\left(\mathrm{S}_{2}\right)\right]}{\left[\mathrm{pH}\left(\mathrm{S}_{2}\right)-\mathrm{pH}\left(\mathrm{S}_{1}\right)\right]} \\
& =\frac{(0,1664-0,0007)}{(6,863-4,005)}=0,0580 \\
& \mathrm{pH}\left(\mathrm{X}_{1}\right)=\mathrm{pH}\left(\mathrm{S}_{1}\right)-\frac{\left[\mathrm{E}_{\mathrm{V}}\left(\mathrm{X}_{1}\right)-\mathrm{E}_{\mathrm{V}}\left(\mathrm{S}_{1}\right)\right]}{k} \\
& \quad=4,005-\frac{(0,1666-0,1664]}{0,0579}=4,00
\end{aligned}
$$

2. Perhitungan Nilai pH Kandidat Bahan Acuan Bufer Fosfat

$$
\begin{aligned}
\mathrm{pH}\left(\mathrm{X}_{2}\right) & =\mathrm{pH}\left(\mathrm{S}_{2}\right)-\frac{\left[\mathrm{E}_{\mathrm{v}}\left(\mathrm{X}_{2}\right)-\mathrm{E}_{\mathrm{v}}\left(\mathrm{S}_{2}\right)\right]}{k^{\prime}} \\
& =6,863-\frac{(0,00073-0,00072]}{0,0579}=6,86
\end{aligned}
$$

Sumber ketidakpastian penentuan nilai $\mathrm{pH}$ kandidat bahan acuan yaitu: ketidakpastian baku CRM yang digunakan untuk mengkalibrasi $\mathrm{pH}$ meter, ketidakpastian baku pengukuran potensial listrik dari CRM yang digunakan, ketidakpastian baku pengukuran potensial listrik dari kandidat bahan acuan yang dibuat, dan ketidakpastian baku dari pengukuran temperatur. Penentuan nilai ketidakpastian tersebut merujuk pada rekomendasi APMP ' $p H$ measurement study in APMP', $2006^{(7)}$. Perhitungan nilai ketidakpastian gabungan (combined uncertainty) dari kandidat bahan acuan bufer ftalat dan bufer fosfat yang dibuat secara berturut-turut disajikan pada Tabel 4 dan Tabel 5.

Dari perhitungan nilai $\mathrm{pH}$ dan ketidakpastian kandidat bahan acuan, disimpulkan bahwa pada tingkat kepercayaan $95 \%(\mathrm{k}=2)$, nilai $\mathrm{pH}$ kandidat bahan acuan bufer Ftalat adalah 4,00 $\pm 0,01$ dan bufer fosfat adalah $6,86 \pm 0,01$.

Uji homogenitas dilakukan dengan mengukur nilai $\mathrm{pH}$ secara duplo dari 10 botol sampel kandidat bahan acuan yang dipilih secara acak. Hasil pengukuran $\mathrm{pH}$ dari 10 kandidat bahan acuan tersebut disajikan pada Tabel6.

Tabel 4. Perhitungan Nilai Ketidakpastian Gabungan Kandidat Bahan Acuan Bufer Ftalat

\begin{tabular}{cccccc}
\hline Faktor & $\begin{array}{c}\text { Unit } \\
\text { Faktor }\end{array}$ & $\begin{array}{c}\text { Ketidakpastian } \\
\text { baku }\end{array}$ & $\begin{array}{c}\text { Koefisien } \\
\text { sensitivitas }\end{array}$ & $\begin{array}{c}\text { Unit } \\
\text { koefisien } \\
\text { sensitivitas }\end{array}$ & $\begin{array}{c}\text { Kontribusi } \\
\text { ketidakpastian }\end{array}$ \\
\hline $\mathrm{pH}\left(\mathrm{S}_{1}\right)$ & 1 & 0,0015 & 1,00013 & 1 & 0,0015 \\
\hline $\mathrm{pH}\left(\mathrm{S}_{2}\right)$ & 1 & 0,0015 & $-0,00013$ & 1 & $2,08 \times 10^{-6}$ \\
\hline $\mathrm{E}_{v}\left(\mathrm{~S}_{1}\right)$ & $\mathrm{V}$ & 0,00016 & 17,27 & $1 / \mathrm{V}$ & 0,003 \\
\hline $\mathrm{E}_{\mathrm{v}}\left(\mathrm{S}_{2}\right)$ & $\mathrm{V}$ & 0,00017 & $-0,024$ & $1 / \mathrm{V}$ & $3,98 \times 10^{-6}$ \\
\hline $\mathrm{E}_{\mathrm{v}}(\mathrm{X})$ & $\mathrm{V}$ & 0,00016 & $-17,25$ & $1 / \mathrm{V}$ & 0,003 \\
\hline $\mathrm{T}$ & $\mathrm{K}$ & 0,115 & $-0,004$ & $1 / \mathrm{K}$ & 0,0004 \\
\hline & & & \multicolumn{2}{l}{ Ketidakpastian gabungan } & 0,005 \\
\hline
\end{tabular}

Tabel 5. Perhitungan Nilai Ketidakpastian Gabungan Kandidat Bahan Acuan Bufer Fosfat

\begin{tabular}{cccccc}
\hline Faktor & $\begin{array}{c}\text { Unit } \\
\text { Faktor }\end{array}$ & $\begin{array}{c}\text { Ketidakpastian } \\
\text { baku }\end{array}$ & $\begin{array}{c}\text { Koefisien } \\
\text { sensitivitas }\end{array}$ & $\begin{array}{c}\text { Unit koefisien } \\
\text { sensitivitas }\end{array}$ & $\begin{array}{c}\text { Kontribusi } \\
\text { ketidakpastian }\end{array}$ \\
\hline $\mathrm{pH}\left(\mathrm{S}_{1}\right)$ & 1 & 0,0015 & $6,04 \times 10^{-5}$ & 1 & $9,05 \times 10^{-8}$ \\
\hline $\mathrm{pH}\left(\mathrm{S}_{2}\right)$ & 1 & 0,0015 & 0,99 & 1 & 0,0015 \\
\hline $\mathrm{E}_{\mathrm{v}}\left(\mathrm{S}_{1}\right)$ & $\mathrm{V}$ & 0,00016 & 0,001 & $1 / \mathrm{V}$ & $1,66 \times 10^{-7}$ \\
\hline $\mathrm{E}_{\mathrm{v}}\left(\mathrm{S}_{2}\right)$ & $\mathrm{V}$ & 0,00016 & 17,25 & $1 / \mathrm{V}$ & 0,003 \\
\hline $\mathrm{E}_{\mathrm{v}}(\mathrm{X})$ & $\mathrm{V}$ & 0,00036 & $-17,25$ & $1 / \mathrm{V}$ & 0,006 \\
\hline $\mathrm{T}$ & $\mathrm{K}$ & 0,115 & $-0,019$ & $1 / \mathrm{K}$ & 0,002 \\
\hline & & & \multicolumn{2}{c}{ Ketidakpastian gabungan } & 0,007 \\
\hline
\end{tabular}

Tabel 6. Nilai pH Uji Homogenitas Kandidat Bahan Acuan

\begin{tabular}{ccccc}
\hline & \multicolumn{4}{c}{ Nilai pH Kandidat Bahan Acuan } \\
\cline { 2 - 5 } No. Botol & \multicolumn{2}{c}{ Bufer Ftalat } & \multicolumn{2}{c}{ Bufer Fosfat } \\
\cline { 2 - 5 } & Pengukuran I & Pengukuran II & Pengukuran I & Pengukuran II \\
\cline { 2 - 5 } 1. & 4,01 & 4,01 & 6,86 & 6,87 \\
\hline 2. & 4,01 & 4,01 & 6,87 & 6,87 \\
\hline 3. & 4,01 & 4,01 & 6,86 & 6,86 \\
\hline 4. & 4,01 & 4,01 & 6,86 & 6,86 \\
\hline 5. & 4,01 & 4,01 & 6,87 & 6,87 \\
\hline 6. & 4,01 & 4,01 & 6,87 & 6,87 \\
\hline 7. & 4,01 & 4,00 & 6,86 & 6,86 \\
\hline 8. & 4,01 & 4,00 & 6,87 & 6,87 \\
\hline 9. & 4,01 & 4,01 & 6,87 & 6,87 \\
\hline 10. & 4,01 & 4,00 & 6,87 & 6,87 \\
\hline
\end{tabular}

Berdasarkan uji $\mathrm{F}$, kandidat bahan acuan bufer ftalat dinyatakan homogen dengan $\mathrm{F}_{\text {hitung }}<\mathrm{F}_{\text {tabel }}$ (hasil perhitungan uji-F pada Tabel 7). 
Tabel 7. Uji F untuk Penentuan Homogenitas Kandidat Bahan Acuan Bufer Ftalat

\begin{tabular}{ccc}
\hline \multirow{2}{*}{ No. Botol } & \multicolumn{2}{c}{ Nilai pH Bufer Ftalat } \\
\cline { 2 - 3 } & Pengukuran I & Pengukuran II \\
\hline 1. & 4,01 & 4,01 \\
\hline 2. & 4,01 & 4,01 \\
\hline 3. & 4,01 & 4,01 \\
\hline 4. & 4,01 & 4,01 \\
\hline 5. & 4,01 & 4,01 \\
\hline 6. & 4,01 & 4,01 \\
\hline 7. & 4,01 & 4,00 \\
\hline 8. & 4,01 & 4,00 \\
\hline 9. & 4,01 & 4,01 \\
\hline 10. & 4,01 & 4,00 \\
\hline
\end{tabular}

Analisis ANOVA menggunakan excel

\begin{tabular}{lcccccc}
\hline Source of Variation & $S S$ & $d f$ & $M S$ & $F$ & $P$-value & F crit \\
\hline Between Groups & 0.000105 & & $1.17 \mathrm{E}-$ & .777778 & 0.642025 & 3.020383 \\
& & & 05 \\
Within Groups & 0.00015 & 10 & $1.5 \mathrm{E}-05$ \\
\hline & & & & & \\
\hline Total & 0.000255 & 19 & & & & \\
\hline
\end{tabular}

$\mathrm{F}_{\text {hitung }}=0,78$

$\mathrm{F}_{\text {tabel }}=3,02$

Karena $\mathrm{F}_{\text {hitung }}<\mathrm{F}_{\text {tabel }}$, maka sampel homogen

Sedangkan untuk bufer fosfat, kandidat bahan acuan dinyatakan tidak homogen berdasarkan uji $\mathrm{F}$. Akan tetapi berdasarkan perhitungan simpangan baku sampling, secara statistik diperoleh bahwa kandidat bahan acuan bufer fosfat dinyatakan homogen, dimana $\mathrm{S}_{\mathrm{s}}<0,5 \mathrm{SD}_{\text {Horwitz }}$ (hasil uji standar deviasi pada sampling pada Tabel 8).

Tabel 8. Perhitungan Standar Deviasi untuk Uji Homogenitas Kandidat Bahan Acuan Bufer Fosfat

\begin{tabular}{ccc}
\hline \multirow{2}{*}{ No. Botol } & \multicolumn{2}{c}{ Nilai pH Bufer Fosfat } \\
\cline { 2 - 3 } & Pengukuran I & Pengukuran II \\
\hline 1. & 6,86 & 6,87 \\
\hline 2. & 6,87 & 6,87 \\
\hline 3. & 6,86 & 6,86 \\
\hline 4. & 6,86 & 6,86 \\
\hline 5. & 6,87 & 6,87 \\
\hline 6. & 6,87 & 6,87 \\
\hline 7. & 6,86 & 6,86 \\
\hline 8. & 6,87 & 6,87 \\
\hline 9. & 6,87 & 6,87 \\
\hline 10. & 6,87 & 6,87 \\
\hline Rata-rata & 6,866 & 6,867 \\
\hline
\end{tabular}

\section{Analisis ANOVA menggunakan excel}

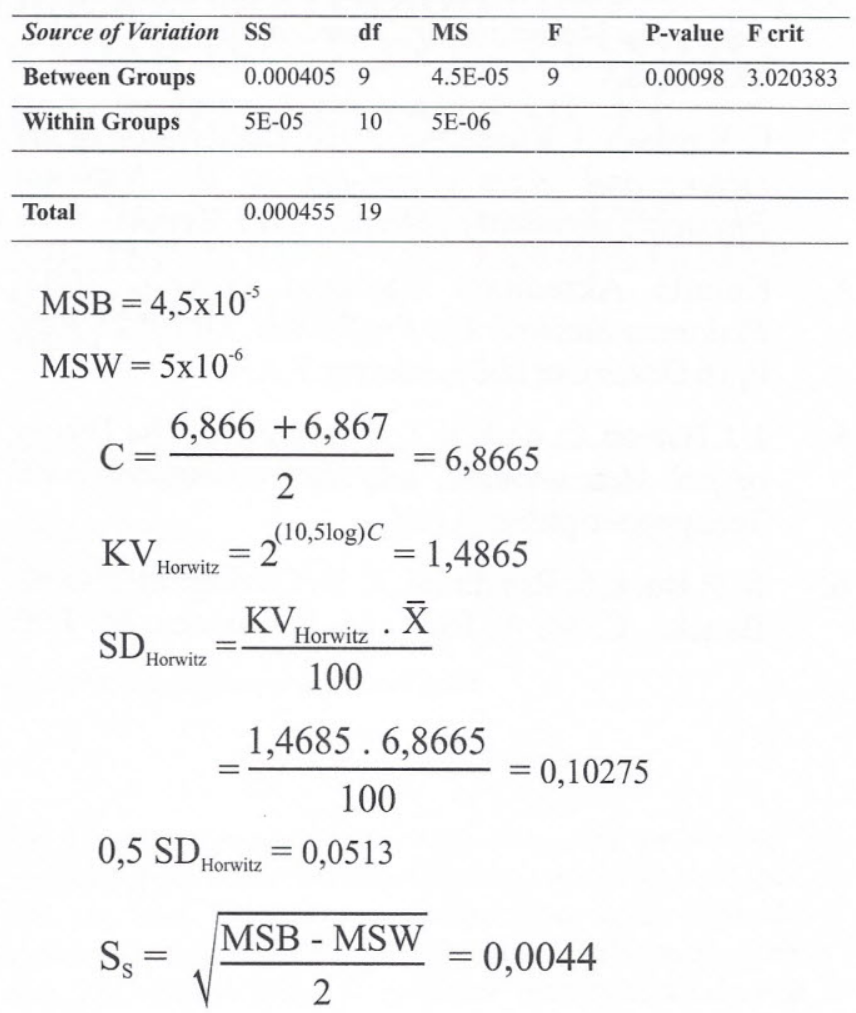

Karena $\mathrm{S}_{\mathrm{s}}<0,5 \mathrm{SD}_{\text {Horwity }}$, maka sampel homogen

Sehingga berdasarkan uji statistik dapat disimpulkan bahwa kedua kandidat bahan acuan yang dibuat sudah homogen.

\section{KESIMPULAN}

Pusat Penelitian Kimia-LIPI sebagai laboratorium rujukan pelaksana teknis metrologi kimia di Indonesia melakukan kegiatan penelitian pembuatan bahan acuan/CRM (Certified Reference Materials). Saat ini salah satu bahan acuan yang sedang dikembangkan adalah bufer ftalat dan bufer fosfat untuk pengukuran $\mathrm{pH}$. Nilai $\mathrm{pH}$ kandidat bahan acuan bufer ftalat dan bufer fosfat yang dibuat berturut-turut adalah $4,00 \pm 0,01$ dan $6,86 \pm 0,01$. Uji homogenitas secara statistik yaitu dengan uji $\mathrm{F}$ dan perhitungan simpangan baku sampling menunjukkan bahwa kedua kandidat bahan acuan yang dibuat telah homogen. Untuk ke depan perlu dilakukan uji stabilitas jangka pendek dan jangka panjang terhadap bahan acuan yang dibuat.

\section{DAFTAR PUSTAKA}

1. Sujarwo, 2011, Ketertelusuran Pengukuran pH dalam Metrologi Kimia, Warta Kimia Analitik (WKA) No. 19 Tahun XVI 
2. M. Stoeppler, W. R. Wolf, P. J. Jenks, 2001, Reference Materials for Chemical Analysis, Wiley VCH, USA

3. E. Kardash, I. Kuselman, 2010, Calibration of pH meters and glass electrodes at the National Physical Laboratory of Israel, INPL Report

4. Komite Akreditasi Nasional (KAN), 2005, Pedoman Statistik Uji Profisiensi, DPLP 23 Rev. 0,16 Desember 2005, Jakarta: KAN

5. J. J. Barron, C. Asthon, L. Geary, 2009, The Theory of $p H$ Measurement, http://www.reagecon.com/ Techpapper/phfaqv4.pdf

6. R. P. Buck, S. Rondinini, A. K. Covington, F. G. K. Baucke, C. M. A. Brett, M. F. Camoes, M. J. T.
Milton, T. Mussini, R. Naumann, K. W. Pratt, P. Spitzer, G. S Wilson, 2002, Measurement of $p H$ Definition, Standards, and Procedures (IUPAC Recommendation 2002), Pure Appl. Chem., Vol 74, No. 11, pp 2169-2200

7. S. Nakamura, A. K. Agrawal, K. Kim, Y. Lim, E. Hwang, Y. Hanaoka, K. S. Hideyuki, H. Fushimi, S. Kawamoto, I. Maksimov, M. Ohata, Y. Yoshinaga, K. H. Mohd, O. Zakaria, M. Mamplata, A. Kimura, A. Chuasuwan, N. Chaengthong, N. Tangpaisankurl, 2006, APMP.QM-P09 pH measurement study in APMP ' $\mathrm{pH}$ determination of phthalate buffer by Harned cell method and glass electrode method', National Institute Metrology of Japan (NMIJ) 